\title{
СРАВНИТЕЛЬНАЯ ОЦЕНКА ПРОТЕОЛИТИЧЕСКОЙ АКТИВНОСТИ ИРРИГАНТОВ, ИСПОЛЬЗУЕМЫХ В МЕДИКАМЕНТОЗНОЙ ОБРАБОТКЕ КОРНЕВЫХ КАНАЛОВ
}

\section{Баязова Ольга Алексеевна \\ студент}

\section{Нурметов Навруз Шухратович}

студент

Научный руководитель: Вусатая Елена Владимировна к.м.н., ассистент кафедры госпитальной стоматологии ФГБОУ ВО «Воронежский государственный медицинский университет им. Н.Н. Бурденко» Министерства здравоохранения Российской Федерации

Аннотация: Эндодонтическое лечение представляет собой медикаментозную и механическую обработку корневых каналов. Для врачастоматолога - это сложная работа, которая проводится практически вслепую. Промывание корневых каналов является одним из главных этапов в эндодонтическом лечении. В ходе медикаментозной обработки уничтожается инфекция, которая находятся в просвете каналов. Это проводится для того, чтобы спасти зуб, предупредить возникновение осложнений и не допустить развития вторичной инфекции. Цель. Сравнить и проанализировать протеолитическую активность препаратов, используемых для промывания корневых каналов. Методы. Для определения протеолитической активности использовались теоретические, эмпирические и математические методы исследования. Результаты. Были выбраны антисептические препараты, в которые помещались кусочки куриных грудок одинаковые по массе. По истечению 24 часов сравнивался вес куриных грудок после полного погружения и нахождения в растворе с исходным. Проведя специальные расчеты, мы определили протеолитическую активность препаратов. Заключение. В результате исследования мы выяснили, что наибольшей протеолитической активностью обладает «Белодез», а наименьшей «Хлоргексидин».

Ключевые слова: медикаментозная обработка корневых каналов, ирригация, протеолитическая активность гипохлорита натрия, антисептики, эндодонтия. 
COMPARATIVE EVALUATION OF THE PROTEOLYTIC ACTIVITY OF IRRIGANTS USED IN THE MEDICAL TREATMENT OF ROOT CANALS

\author{
Bayazova Olga Alekseevna \\ Scientific adviser: Vusataya Elena Vladimirovna
}

\begin{abstract}
Endodontic therapy consists of medical and mechanical root canal treatment. This is rather a challenge for a dentist who has to work practically blindfolded. Irrigation of root canals is one of the main steps in endodontic therapy. Medical treatment destroys the infection in the root end opening. This is a toothsaving measure taken to prevent complications and secondary infections. Purpose. The purpose of this research is to compare and analyze proteolytic activity of antiseptics used for irrigation of root canals. Methods. The determination of proteolytic activity required research methods as follows: theoretic, empirical and mathematical. Outcome. Pieces of chicken breast of the same weight (initial wight) were fully submerged in antiseptics, earlier selected for the test. 24 hours later the chicken breasts were taken out and their weight was compared with the initial weight. Having done some necessary calculations we determined the proteolytic activity of the antiseptics. Conclusion. The research shows that Belodez has the highest proteolytic activity, while Chlorhexidine has the lowest.
\end{abstract}

Key words: medical root canal treatment, irrigation, proteolytic activity of sodium hypochlorite, antiseptics, endodontic.

Актуальность. Чтобы разобраться, почему так важна протеолитическая активность препаратов, используемых в медикаментозной обработке корневых каналов, необходимо рассмотреть клеточную стенку инфекционного агента. Она содержит белки, жиры и углеводы. Каркас клеточной стенки по большей части состоит из белкового компонента $[1$, с. 134]. Следовательно, антисептические препараты, используемые в корневых каналах, должны обладать высокой протеолитической активностью, чтобы уничтожить как можно больше инфекционных агентов в корневых каналах [2, с. 198].

Какой антисептик обладает наибольшей протеолитической активностью? Чтобы ответить на этот вопрос, мы провели эксперимент, в котором сравнили разные виды антисептических препаратов, используемых при медикаментозной обработке в эндодонтиии. 
Цель. Проанализировать и сравнить протеолитическую активность антисептических препаратов, используемых используемых при медикаментозной обработке в эндодонтиии.

Методы. Протеолитическая активность расчитывалась по формуле (M1M2):M1*100\%, где M1 - масса куриной грудки до действия раствора антисептика, а М2 - масса куриной грудки после действия раствора антисептика. Для эксперимента мы решили использовать 4 антисептика: 2\% раствор хлоргексидина биглюконата - «Хлоргексидин», 3\% раствор перекиси водорода - «Перикись водорода», 3\% раствор гипохлорита натрия «Белодез»и «Йодинол». Куриные грудки, весом 4г, поместили в 4 емкости, в каждой из которых находился определенный антисептический раствор. Через 24 часа произвели контрольное взвешивание и зафиксировали результат.

Результаты.

В результате нашего исследования после помещения куриной грудки в «Белодез» масса уменьшилась на 3 г, в «Йодинол» на 2 г, в «Перекись водорода» на 2г. После «Хлоргексидина» масса не изменилась. Следовательно протеолитическая активность «Белодез» составляет 12,5\% , «Хлоргексидина» - 0\%, «Йодинол» - 8,33\%, «Перекись водорода» - 8,33\% (табл.1). По нашему мнению, объяснить подобные результаты можно следующим образом. Хлоргексидин уничтожает микроорганизмы путем изменения проницаемости мембраны, связываясь с фосфолипидами и вытесняя соединения двухвалентных катионов, он не воздействует на белковые структуры клеток [3, с. 101]. Перекись водорода способствует потере биологической активности органических соединений, что подтверждает протеолитическую активность [4, с. 145]. Йодинол обладает бактерицидным действием за счет разрушения белков мембраны микроорганизмов [5, с. 78]. «Белодез», он же гипохлорит натрия, нейтрализует аминокислоты, вызывает их дегидратацию и гидролиз, превращая их в соль и воду.

Таблица 1

\begin{tabular}{|c|c|}
\hline Ирригант & Протеолитическая активность (\%) \\
\hline 3\% гипохлорит натрия & 12,5 \\
\hline 3\% перикись водорода & 8,33 \\
\hline Йодинол & 8,33 \\
\hline 2\% хлоргексидин биглюконат & 0 \\
\hline
\end{tabular}


Заключение. Медикаментозная обработка корневых каналов производится с помощью растворов антисептиков. Они могут быть совершенно разными и у каждого препарата свой механизм действия и своя задача. В ходе исследования мы выяснили, что самой большой протеолитической активностью обладает «Белодез», а самой низкой «Хлоргексидин». Это объясняется механизмом действия данных препаратов.

\section{Список литературы}

1. Ламли, Ф. Практическая клиническая эндодонтия / Ф. Ламли. - М.: МЕДпресс-информ, 2018. - 374 с.

2. Коэн С., Бернс Р. Эндодонтия: учебное пособие / С Коэн. M.:STBOOK, 2007. - 1040 c.

3. Данилевский Н.Ф. Пульпит: учебное пособие. - М: Здоровья, 2003 $168 \mathrm{c}$.

4. Иванов В.С., Урбанович Л.И. Воспаление пульпы зуба / В.П. Бережной - М: Медицина, $1990-208$ с.

5. Бритова, А.А. Стоматология. Эндодонтия : учебное пособие для вузов / А.А. Бритова. - 2-е изд., перераб. и доп. - Москва : Издательство Юрайт, 2019. - 198 c. 